\title{
What is Statutory Purpose?
}

\section{Dale Smith*}

Over the past few decades, an impressive body of work has developed exploring theoretical issues relating to statutory interpretation. Philosophically-informed accounts of the meaning (or, as I shall say, the linguistic content) of statutory provisions have been proposed. Theories of legislative intent have become more sophisticated, and the sceptical challenge to the existence or utility of legislative intent has been refined in important respects. Increasingly rigorous accounts of textualism and intentionalism have been offered, as well as some robust challenges to the distinction between these two schools of thought.

Jeff Goldsworthy has been in the vanguard of these developments. Since the early 1990s, he has offered a sophisticated, neo-Gricean account of the linguistic content of constitutional and statutory texts. ${ }^{1}$ He has also played an important role in the debate about whether intentions can be ascribed to the legislature and, if so, on what basis. ${ }^{2}$

At the same time, less effort has been made to better understand the concept of statutory purpose, or to explore the role that purpose does or should play in statutory interpretation. This is, of course, a broad generalisation. For example, while it is not the central theme in Goldsworthy's writings about statutory interpretation, we will see that he offers an interesting and suggestive account of statutory purpose. Nevertheless, when one considers the amount of work that has been done to better understand the linguistic content of statutory provisions and on legislative intent, and to develop interesting and plausible versions of textualism and

\footnotetext{
* Melbourne Law School, University of Melbourne. Earlier versions of this paper were presented at a workshop at Monash University to commemorate the retirement of Professor Jeff Goldsworthy, and at a workshop at Sydney Law School to commemorate the retirement of Professor Tom Campbell. I am very grateful to audience members at both events. I am especially grateful to Farrah Ahmed for extremely helpful comments on an earlier draft, and to Jeff Goldsworthy for his very helpful advice about this paper and about much else over the past 17 years. This research was supported under the Australian Research Council's Discovery Projects funding scheme (project number DP140102670).

${ }^{1}$ See, eg, J Goldsworthy, 'Implications in Language, Law and the Constitution' in G Lindell (ed), Future Directions in Australian Constitutional Law: Essays in Honour of Professor Leslie Zines (Sydney, Federation Press, 1994) 150; J Goldsworthy, 'Moderate Versus Strong Intentionalism: Knapps and Michaels Revisited' (2005) 42 San Diego Law Review 669; J Goldsworthy, 'Constitutional Implications Revisited' (2011) 30 University of Queensland Law Journal 9.

${ }^{2}$ See, eg, J Goldsworthy, Parliamentary Sovereignty: Contemporary Debates (Cambridge, Cambridge University Press, 2010) 232-51; R Ekins and J Goldsworthy, 'The Reality and Indispensability of Legislative Intentions' (2014) 36 Sydney Law Review 39; J Goldsworthy, 'Legislative Intention Vindicated?' (2013) 33 OJLS 821.
} 
intentionalism, it is fair to say that comparatively little attention has been paid to statutory purpose.

Indeed, there is no consensus - among theorists or practitioners - about what statutory purpose is. It is common for judges to appeal to statutory purpose, and for commentators to discuss the appropriate role of statutory purpose, without explaining what they mean by the term. Even where an explicit characterisation is provided, we shall see that there are at least three schools of thought regarding how statutory purpose is to be understood, and there has been minimal dialogue between those schools of thought.

This should be of concern. Appeals to purpose appear to play a prominent role in judicial reasoning about statutes, and in judges' characterisation of their interpretive practices. ${ }^{3}$ Legislatures, too, appear to take the concept seriously. In many jurisdictions, it is common for a statute to contain an express statement of (what the legislature takes to be) its purpose, whether in a preamble or an objects clause. And, in some jurisdictions, there is a statutory requirement that courts interpret legislation in a way that promotes the statutory purpose. ${ }^{4}$

It seems important, therefore, that we have a clear understanding of what statutory purpose is, and of what role it does and should play in statutory interpretation. Perhaps we should be sceptical about judicial and legislative invocations of statutory purpose. Objects clauses are often notoriously unhelpful, and courts sometimes read down statutory requirements to privilege the interpretation that (best) promotes the statutory purpose. ${ }^{5}$ Moreover, there are well-known objections to judicial reliance on statutory purpose, some of which are discussed below. Nevertheless, whether or not we ultimately arrive at a sceptical conclusion, we should first ensure that we understand the concept whose utility is being questioned.

\footnotetext{
${ }^{3}$ In the UK, see, eg, Attorney-General's Reference (No 5 of 2002) [2004] 4 All ER 901 at [31]; in Australia, see, eg, Project Blue Sky Inc v Australian Broadcasting Authority (1998) 194 CLR 355 at [69]. In the US, even Justice Scalia has acknowledged that statutory purpose has an important - though limited - role to play: see nn 69-71 below.

${ }^{4}$ These statutory requirements come in differing strengths. In some jurisdictions, the interpretation that best promotes the statutory purpose must be preferred: see, eg, Acts Interpretation Act 1901 (Cth), s 15AA. In other jurisdictions, the requirement is merely that an interpretation that promotes the statutory purpose be preferred to one that does not: see, eg, Interpretation of Legislation Act 1984 (Vic), s 35(a). In the latter case, the statutory requirement says nothing about a situation in which two interpretations each promote the statutory purpose, but to different extents. See Chugg v Pacific Dunlop Ltd (1990) 170 CLR 249 at 262.

${ }^{5}$ See, eg, Thiess $v$ Collector of Customs (2014) 250 CLR 664 at 672.
} 
The aim of this paper is to advance our understanding of what statutory purpose is, as a precursor to considering what role (if any) it does and should play in statutory interpretation. I begin, in Part I, by identifying three approaches to understanding the concept of statutory purpose. Statutory purpose has variously been equated with the intentions of certain legislators (or the legislature as a whole), with the intentions that a reasonable legislator would have had if he or she had enacted the statute, and with some 'objective' purpose that may depart from any intentions that (actual or reasonable) legislators may have had. I shall suggest that there appear to be significant problems with each of these approaches.

In Part II, I suggest a way of understanding the first approach - which equates statutory purpose with the intentions of the legislature, or of certain legislators - that avoids many of the objections to that approach. I start by distinguishing between the legislature's communicative intentions and its legal intentions, before suggesting that statutory purpose is concerned with the latter. I then consider whether legal intentions should be understood as directed toward the norm that the statutory provision is to contribute to the content of the law ('norm-intentions') or toward the state of affairs that the provision is to bring about ('application-intentions'). While the former suggestion may appear attractive, I argue that we should understand legal intentions in terms of application-intentions. However, the legislature may have multiple application-intentions with regard to a single statute, only some of which should count as part of the statutory purpose. Thus, I go on to suggest some constraints on which of the legislature's application-intentions count. I finish by addressing the possibility that different legislators will have different application-intentions.

\section{Three Understandings of Statutory Purpose}

There are at least three broad understandings of statutory purpose reflected in the literature. Some writers treat statutory purpose as equivalent to certain intentions of the legislature (or of a certain set of legislators). ${ }^{6}$ Others understand it in terms of the intentions that a reasonable legislator would have had, had they enacted the statute in question. Finally, statutory purpose

\footnotetext{
${ }^{6}$ For ease of exposition, I shall talk of the intentions of 'the legislature', understanding this to cover both the possibility that the relevant intentions are held by the legislature in its own right and the possibility that the relevant intentions are those shared by certain legislators (which are then attributed to the legislature as a whole). Of course, many people are sceptical about whether legislatures can have intentions in either sense. I discuss this sort of scepticism below.
} 
is sometimes understood as some sort of 'objective' purpose, separate from any intention of the legislature. I shall suggest that, if it is not to collapse into the second approach, this third approach is best understood as concerned with the functional role that the statute plays within the legal system.

In this Part, I explore these understandings of statutory purpose in greater depth, and contend that each appears to face substantial obstacles. This will set the scene for Part II, where I offer a version of the first approach - which understands statutory purpose in terms of certain intentions of the legislature - that avoids many of those obstacles.

Before commencing, three caveats are called for. First, the three approaches I discuss are not exhaustive: not everyone who writes about statutory purpose endorses, or presupposes, one of these accounts. ${ }^{7}$ However, each of the three approaches has been suggested by influential writers on the topic, and at least the first two are widely held. As will emerge, all three approaches also raise theoretically important issues.

Second, the three understandings of statutory purpose I discuss may not be mutually exclusive. Indeed, we shall see that some writers appear to endorse two of the three approaches. In doing so, they are not necessarily being inconsistent. It is possible that we use the phrase 'statutory purpose' to pick out more than one factor relevant to the interpretation of legislation. Or it may be that there are multiple purposes in play (eg a specific and a broader purpose), each of which is to be understood in a different way.

Third, I should say something about the type of problem with which I shall be concerned in this Part. There are well-known objections to all but the most limited use of statutory purpose. ${ }^{8}$ For example, it is argued that more extensive uses of purpose undermine the carefully crafted compromises that are made in the legislative process and reflected in the

\footnotetext{
${ }^{7}$ In particular, I leave to one side morally-laden conceptions of statutory purpose that take their place within a broader, anti-positivist theory of law. Such conceptions include the view that statutory purpose is an interpretive concept (see R Dworkin, Law's Empire (Oxford, Hart Publishing, 1998) 346 for hints of this view), and Michael Moore's claim that a statute's purpose is 'the function [the] statute serves in an ideally just and well-ordered society' (MS Moore, 'A Natural Law Theory of Interpretation' (1985) 58 Southern California Law Review 277, $354)$.

${ }^{8}$ I say more about which uses of statutory purpose are relatively uncontroversial in the text accompanying nn 6971 below.
} 
statutory text. ${ }^{9}$ It is also objected that permitting judges to interpret a statute in light of its purpose confers on the judiciary enormous discretion (eg in deciding which of several possible purposes to privilege) and/or runs the risk that judges will abuse their position by attributing to the statute the purpose they believe it should have. ${ }^{10}$ However, my primary focus is not on these sorts of objections. Rather, it is on objections that are specific to the particular understandings of statutory purpose I consider. That is, my main concern is with objections to understanding statutory purpose in a certain way, not with objections to certain uses of statutory purpose. (Admitedly, the two sets of objections may be related. For example, it may be an objection to a particular understanding of statutory purpose that it exacerbates the concerns about the use of purpose in statutory interpretation.)

\section{A. Statutory Purpose and Legislative Intent}

A common way of understanding the concept of statutory purpose is in terms of certain intentions of the legislature. For example, Goldsworthy claims that 'A purpose is a kind of intention: an intention to achieve something. ${ }^{11} \mathrm{He}$ infers from this that, strictly speaking, legal texts such as statutes cannot have purposes (because they cannot have intentions). Rather, a reference to the purpose of a legal text should be understood as a reference to the purpose (ie the intention) of the people who designed or used that text. ${ }^{12}$ In the case of statutes, the purpose is naturally understood in terms of the intentions of the law-maker - that is, the legislature. ${ }^{13}$

One appealing feature of this approach is that it fits with linguistic usage in other contexts, where we often use 'purpose' and 'intention' interchangeably. For example, we might say that both my intention and my purpose in walking quickly to the station is to arrive in time to catch the next train. However, there appear to be significant problems with treating 'purpose'

\footnotetext{
9 See, eg, JF Manning, 'What Divides Textualists from Purposivists?' (2006) 106 Columbia Law Review 70, 92, 96, 99-109.

${ }^{10}$ See, eg, A Scalia and BA Garner, Reading Law: The Interpretation of Legal Texts (St Paul, Thomson/West, 2012) 18-19; A Scalia, A Matter of Interpretation (Princeton, Princeton University Press, 1997) 17-18.

11 J Goldsworthy, 'Functions, Purposes and Values in Constitutional Interpretation' in R Dixon (ed), Australian Constitutional Values (Oxford, Hart Publishing, 2018) 45. See also Goldsworthy, Parliamentary Sovereignty (n 2) 233.

12 Goldsworthy, 'Functions, Purposes and Values' (n 11) 45; Goldsworthy, Parliamentary Sovereignty (n 2) 233.

${ }^{13}$ While Goldsworthy sometimes leaves open the question of whether it is the designer's or the user's intentions that count, in the case of statutes he generally focuses on the legislature's intentions: see, eg, Goldsworthy, Parliamentary Sovereignty (n 2) 233. Other commentators have also understood statutory purpose in terms of certain intentions of the law-maker: see, eg, N Duxbury, Elements of Legislation (Cambridge, Cambridge University Press, 2012) 176.
} 
and 'intention' as interchangeable in the context of statutory interpretation. For one thing, it is controversial whether the legislature can have intentions, given that it consists of a multitude of members who may have conflicting (or no) intentions with regard to a particular statute. ${ }^{14}$ If statutory purpose is understood in terms of the legislature's intentions but the legislature cannot have intentions, then there is no such thing as statutory purpose.

I shall not seek to resolve the debate about legislative intent in this paper. I do, however, want to suggest that this debate does not pose a distinct problem for writers such as Goldsworthy, who understand statutory purpose in terms of certain intentions of the legislature. If legislatures cannot have intentions, then the implications go far beyond issues of statutory purpose. Obviously, it would follow that references to legislative intent - and hence any version of intentionalism - are also problematic. And it would be doubtful that any linguistic content could be attributed to statutes beyond the semantic meaning of the words in the statute, since mainstream philosophy of language treats pragmatic content as a function of the speaker's intentions. ${ }^{15}$ This would render questionable any attempt to (say) fill ellipses in, or draw implications from, the statutory text, at least if this is meant to involve identifying the statute's linguistic content. ${ }^{16}$ And scepticism about legislative intent seems to entail a more general scepticism about ascribing mental states - any mental state, not just intentions - to any multimember body whose members may have conflicting beliefs, desires, intentions, etc. This would extend to many corporations and associations, and to appellate courts. ${ }^{17}$

None of this shows that sceptics about legislative intent are mistaken, or provides any insight into how intentions are to be ascribed to legislatures. However, it does suggest that, if scepticism about legislative intent is a problem for advocates of the present understanding of statutory purpose, they have plenty of company.

\footnotetext{
${ }^{14}$ Compare R Dworkin, A Matter of Principle (Cambridge MA, Harvard University Press, 1985) 38-57 with Ekins and Goldsworthy (n 2).

${ }^{15}$ See generally D Smith, 'Is the High Court Mistaken about the Aim of Statutory Interpretation?' (2016) 44 Federal Law Review 227, 237; Ekins and Goldsworthy (n 2) 56-57. Concerning the distinction between semantic and pragmatic content, see D Smith, 'The Practice-Based Objection to the Standard Picture' (unpublished MS) 3. ${ }^{16}$ Goldsworthy, Parliamentary Sovereignty (n 2) 236-38. There is room for disagreement about how big a problem this is. For example, Andrei Marmor claims that pragmatic enrichment is often (but not always) precluded in the legislative context anyway, independent of any general scepticism about legislative intent: A Marmor, 'The Pragmatics of Legal Language' (2008) 21 Ratio Juris 423.

${ }^{17}$ In Zheng v Cai (2009) 239 CLR 446, the High Court of Australia treated as unproblematic the suggestion that a church (an incorporated association) has intentions, while expressing scepticism about the possibility that a legislature could have intentions (at [27]-[28]). The Court did not explain how these positions could be reconciled, beyond asserting that the context is different. (I am grateful to Lisa Burton Crawford and Patrick Emerton for drawing the discussion in Zheng to my attention.)
} 
There is a more troubling objection to the present understanding of statutory purpose. Legislative intent and statutory purpose are usually thought of as discrete concepts. The relationship between the two is disputed. Some people think of statutory purpose as contributing to, or shedding light on, legislative intent. Others regard statutory purpose and legislative intent as separate constituents of a statute's legal effect. ${ }^{18}$ However, if it is to play any of these roles, statutory purpose must be conceptually distinct from legislative intent. Yet, if statutory purpose is understood in terms of the legislature's intentions, the distinction between legislative intent and statutory purpose seems to vanish.

The standard response to this problem is to treat statutory purpose as a particularly broad or general intention. For example, Lawrence Solan suggests that legislative intent refers to the more specific goals the legislature had in enacting the statute, whereas statutory purpose refers to the legislature's more abstract goals. ${ }^{19}$ Similarly, Neil Duxbury suggests that we can distinguish between legislative intent and statutory purpose on the basis that references to the latter are often references to 'general legislative intent.' ${ }^{20}$ This might explain why statutory purpose is sometimes used as evidence of legislative intent (since the legislature's general intention may shed light on its more specific intention), and also why they are sometimes treated as separate contributors to legal effect (if we think that a statute's legal effect is shaped both by the specific intention the legislature had and by its more general aim).

However, to assess whether this response is satisfactory, we need to know more about the distinction between specific and general intentions. When is an intention sufficiently specific to count as the legislative intent, and when is an intention sufficiently general to count as the statutory purpose? We might appeal to the metaphor of a chain or ladder of intentions. The idea behind this metaphor is that, with regard to any statute, the legislature has a number of intentions of varying degrees of specificity, and the more specific intentions are (seen as) ways of achieving the more general intentions. Goldsworthy gives an example in a constitutional context:

\footnotetext{
${ }^{18}$ I understand a statute's legal effect in terms of the contribution the statute makes to the content of the law. For a more detailed discussion, see Smith, 'The Practice-Based Objection' (n 15) 2-3.

${ }^{19}$ LM Solan, The Language of Statutes: Laws and Their Interpretation (Chicago, University of Chicago Press, 2010) 142.

${ }^{20}$ Duxbury (n 13) 176 (footnote omitted).
} 
[C]onstitution-makers may enact a set of words in order to establish a particular constitutional norm, that judicial salaries be fixed, in order to secure judicial independence, in order to secure the impartiality of judicial decision-making, in order to secure justice and the rule of law, in order to promote human dignity (and the chain may or may not end there).. ${ }^{21}$

Transposed to the statutory context, the thought might be that we can distinguish between specific and general intentions by reference to where the intention is located on this ladder of intentions. However, all this tells us is that statutory purpose is higher up the ladder than legislative intent. It does not tell us where to locate either concept on the ladder. ${ }^{22}$ In Goldsworthy's example, is the legislative intent that judicial salaries be fixed or that judicial independence be secured? Is the statutory purpose to secure judicial independence or to secure the impartiality of judicial decision-making (or perhaps even to promote justice and the rule of law)? The distinction between specific and general intentions does not provide a basis on which to answer these questions.

A similar problem confronts the related proposal to understand statutory purpose in terms of the end that the legislature sought to achieve by enacting the statute and legislative intent in terms of the means that the legislature chose to pursue that end. The ladder of intentions metaphor can be understood in terms of a series of intermediate ends, each of which is, in turn, instrumental to achieving the more general ends further up the ladder. We therefore face the same difficulty in deciding where on the ladder to locate legislative intent and statutory purpose.

In addition, there may be reason to characterise statutory purpose in a way that is sensitive, not only to the end the legislature sought to achieve, but also the means it chose to achieve that end. This may result in a more precise characterisation of the statutory purpose, and may help to alleviate an important concern about appeals to purpose - namely, that they

\footnotetext{
${ }^{21}$ Goldsworthy, 'Functions, Purposes and Values' (n 11) 44.

${ }^{22}$ The metaphor of a chain of intentions or purposes dates back to M Radin, 'Statutory Interpretation' (1930) 43 Harvard Law Review 863, 876-78. It is normally invoked as part of a sceptical argument about the utility of statutory purpose. For example, Radin contends that almost any end is itself a means to a further end (which is how the chain is generated), and so judges have a choice about the level of generality at which to describe the statutory purpose. Goldsworthy's discussion of the metaphor is more neutral, but he does not suggest that it can be used to resolve the problem discussed in the text.
} 
overlook the significance of the legislature's choice of the means by which the desired end is to be achieved. ${ }^{23}$

\section{B. Statutory Purpose and Standards of Reasonableness}

We will return to the idea that statutory purpose is to be understood in terms of certain intentions of the legislature in Part II. For now, let us consider an alternative approach that has been particularly influential in the United States. On this approach, statutory purpose is concerned, not with the intentions of the actual legislature, but rather with the intentions (or aims, or goals) that a reasonable legislator would have had if he or she had enacted the statute (on the assumption that he or she was familiar with the statutory text, with other statutes in pari materia and with relevant principles of statutory interpretation). ${ }^{24}$

This view is often traced back to the legal process materials of Hart and Sacks. ${ }^{25}$ They argue that, when identifying the statutory purpose, a court 'should assume, unless the contrary unmistakably appears, that the legislature was made up of reasonable persons pursuing reasonable purposes reasonably., ${ }^{26}$ This, they suggest, involves comparing the new law (ie the law that applies after the enactment of the statute) with the old law (ie the law that applied before the statute was enacted), and asking why reasonable legislators would have enacted the new law to replace the old law.

However, there may be an important difference between Hart and Sacks' view and the approach I want to consider in this Section. Arguably, Hart and Sacks offer advice about how to identify a statute's purpose, rather than making a claim about what statutory purpose is. By contrast, the view I am interested in makes a metaphysical claim about what constitutes statutory purpose, not an epistemic claim about how to identify that purpose.

This understanding of statutory purpose has the virtue of suggesting a clear distinction between legislative intent and statutory purpose. Legislative intent is concerned with the

\footnotetext{
${ }^{23}$ For an expression of this concern, see R Ekins, The Nature of Legislative Intent (Oxford, Oxford University Press, 2012) 250-51.

${ }^{24}$ See Manning (n 9) 90-91 (suggesting that this is the way in which purposivists understand statutory purpose).

${ }^{25}$ HM Hart and AM Sacks, The Legal Process: Basic Problems in the Making and Application of Law (Cambridge MA, Foundation Press, 1994).

${ }^{26}$ Ibid 1415.
} 
intentions of the actual legislature; statutory purpose is concerned with the intentions (or aims, or goals) that a reasonable legislator would have had, had he or she enacted the statute.

Prima facie, this understanding of statutory purpose has another advantage over the understanding considered in the previous Section. Because it equates statutory purpose with the intentions of a reasonable legislator, not those of the actual legislature, it appears that the present view is unaffected by sceptical arguments about legislative intent. Those arguments pertain to whether intentions can be attributed to the actual legislature, and so might be thought to have no bite against the view that statutory purpose is fixed by reference to the intentions of a hypothetical, reasonable legislator. ${ }^{27}$

In the previous Section, I argued that scepticism about legislative intent does not pose a distinctive problem for the suggestion that we should understand statutory purpose in terms of the legislature's intentions. However, to the extent that scepticism about legislative intent does pose a problem for that understanding of statutory purpose, I doubt that the present approach is any better off. A reasonable legislator can have intentions, but so can an actual legislator. The problems arise when we seek to identify which of the legislator's intentions are relevant, and when we seek to move from the intentions of individual legislators to those of the legislature as a whole. ${ }^{28}$ It is not clear that focusing on reasonable, rather than actual, legislators helps here. Even a reasonable legislator may have multiple intentions with regard to a statute, and those intentions may conflict in unforeseen circumstances. (The reasonable legislator is familiar with the statutory text, other statutes in pari materia and relevant principles of statutory interpretation, but is not omniscient.) Similarly, even reasonable people can disagree about controversial legal and political issues, raising doubts about whether we can treat the intentions of any one reasonable legislator as representative. Put differently, on the present proposal, with which reasonable legislator should we be concerned?

There are further problems with the suggestion that statutory purpose should be understood in terms of the intentions that a reasonable legislator would have had. First, it is unclear why the intentions of a hypothetical legislator are of legal significance. They may be of evidential relevance: if we have reason to believe that the actual legislators were reasonable,

\footnotetext{
${ }^{27}$ Manning (n 9) appears to attach great weight to this purported advantage of the present understanding of statutory purpose.

${ }^{28}$ See, eg, Dworkin, A Matter of Principle (n 14) 38-57.
} 
we might consider what a reasonable legislator would have intended as a way of obtaining insight into the intentions of the actual legislators. However, why should we accept the claim that the intentions of a reasonable legislator help constitute a statute's legal effect? To the extent that the authority of a statute flows from the authority of the law-maker, it is the actual legislature's intentions, not those of a hypothetical reasonable legislator, that matter. ${ }^{29}$ It follows that, on the present understanding, it is unclear why we should treat statutory purpose as legally relevant.

We may ultimately conclude that statutory purpose does not help constitute a statute's legal effect, but merely plays an evidential role. However, it is a disadvantage of the present understanding of statutory purpose that it makes that conclusion appear inescapable, without any need to engage with the critiques of the use of statutory purpose (based, for example, on the need to respect legislative compromise) that are usually offered in support of that conclusion.

Second, there are some statutes that no reasonable legislator would have enacted. Of course, judgements of reasonableness vary, and so we are unlikely to agree about which statutes this is true of. Nevertheless, it is likely that most readers will accept that there are some such statutes. It is unclear how we can apply the current suggestion - which requires a consideration of the intentions that a reasonable legislator would have had if he or she had enacted the statute - to statutes that a reasonable legislator would not have enacted. Perhaps the current suggestion supports the conclusion that there is no statutory purpose in such cases. Yet this seems the wrong conclusion to draw. There may be reasons why purpose should not play a role in interpreting a statute that a reasonable legislator would not have enacted, but it is implausible to suggest that the statute has no purpose at all (cf an unreasonable or immoral purpose).

C. Statutory Purpose and Functional Role

\footnotetext{
${ }^{29}$ For the argument that, to the extent that the authority of a legal text flows from the authority of the law-maker, we must attach weight to the (actual) law-maker's intentions, see J Raz, Between Authority and Interpretation: On the Theory of Law and Practical Reason (Oxford, Oxford University Press, 2009) 235.
} 
It is sometimes suggested that statutory purpose consists, at least in part, of some sort of 'objective' purpose. ${ }^{30}$ It is tempting to understand this suggestion as referring to the intentions of a reasonable legislator, rather than those of the actual legislature, in which case it collapses into the approach discussed in the previous Section. ${ }^{31}$ However, there is another way of understanding this suggestion that directs attention away from intentions (whether actual or reasonable). We might think of statutory purpose as constituted by the role the statute plays within the broader legal system, given the other laws that exist within that legal system. On this view, a statute's purpose cannot be understood solely by reference to facts about the statute itself (including facts about the intentions with which the statute was enacted). Rather, it must be understood by reference to the way in which the statute interacts with other relevant legal materials, and this may be at least partly independent of the law-maker's intentions as to how it will interact with those materials.

This suggestion may enjoy some support in the literature. While Hart and Sacks are more commonly associated with the previous understanding of statutory purpose, they may also endorse the present understanding. They suggest that a statute has both a particular purpose and a general purpose. While identifying the particular purpose requires a consideration of the intentions that a reasonable legislator would have had if he or she had enacted the statute, they suggest that the general purpose concerns how the statute 'is to be fitted into the legal system as a whole.' 32

It is possible that Hart and Sacks understand both purposes in terms of the intentions of a reasonable legislator. On this reading, they suggest that a reasonable legislator would have intentions concerning both what the statute will achieve and how it will fit with the rest of the legal system. However, recall that the reasonable legislator's intentions are shaped by his or her awareness of the surrounding legal materials and relevant principles of statutory interpretation. Thus, it might be thought that asking how a reasonable legislator would intend that the statute fit with the rest of the legal system is simply a heuristic for identifying the role

\footnotetext{
${ }^{30}$ For example, Aharon Barak understands statutory purpose in terms of a combination of a 'subjective' purpose (dependent, in part, on the law-maker's intentions) and an 'objective' purpose: A Barak, Purposive Interpretation in Law (Princeton, Princeton University Press, 2005) ch 3.

${ }^{31}$ Barak's account of a statute's objective purpose is complex, incorporating both elements of the 'reasonable legislator' approach and an appeal to 'the fundamental values of the legal system' (ibid 90).

${ }^{32}$ Hart and Sacks (n 25) 1414.
} 
that the statute in fact plays within the broader legal system. ${ }^{33}$ In any case, it is this understanding of statutory purpose that I shall consider in this Section.

Goldsworthy denies that statutes (or other legal texts) can have purposes that are independent of the law-maker in this way. He argues that laws are deliberately created by people, and so the purposes of those laws must be the purposes of the people who created them. ${ }^{34}$ This appears to tie purposes back to intentions (arguably, the intentions of actual people, rather than those of a hypothetical, reasonable person).

In the present context, Goldsworthy treats 'purpose' and 'function' as synonyms. ${ }^{35}$ Thus, his argument appears to be based on a broader claim about the function of artifacts ${ }^{36}$ namely, that their function is fixed by reference to the intentions of the people who create them (or, perhaps, the people who use them). This is a popular view in philosophical writings about artifacts. ${ }^{37}$ However, it is not the only possible view. On another view, an artifact's function is fixed by reference to the role the artifact plays in the world, not the role someone intends it to play. ${ }^{38}$ This suggests that - even if we regard a statute as an artifact and treat its purpose as equivalent to its function - statutory purpose could be understood independently of anyone's intentions, but rather in terms of the role the statute plays in the legal system. Since any statute must take its place within a vast network of other laws, it does not seem implausible to claim that the role the statute plays within the legal system is influenced by those other laws, in ways that may diverge from the intentions the law-maker had when enacting the statute.

So the present proposal for understanding statutory purpose is more plausible than it might appear. Nevertheless, it suffers from a major problem. Perhaps a statute's legal effect is

\footnotetext{
${ }^{33}$ This fits with the suggestion in the previous Section that Hart and Sacks may be offering epistemic guidance as to how we identify statutory purpose, rather than a metaphysical thesis about what constitutes statutory purpose.

${ }^{34}$ Goldsworthy, 'Functions, Purposes and Values' (n 11) 48.

35 Ibid 44.

${ }^{36}$ Following Hilpinen, we can think of an artifact as 'an object that has been intentionally made or produced for a certain purpose' (R Hilpinen, 'Artifact' in EN Zalta (ed), The Stanford Encyclopedia of Philosophy, Winter 2011 edn (URL: plato.stanford.edu/archives/win2011/entries/artifact/)). A statute might be thought to be an artifact in this sense.

${ }^{37}$ See generally AL Thomasson, 'Public Artifacts, Intentions and Norms' in M Franssen, P Kroes, TAC Reydon and PE Vermaas (eds), Artefact Kinds: Ontology and the Human-Made World (Cham, Springer, 2014) 45-46. For an endorsement of this view in the legal context, see KM Ehrenberg, The Functions of Law (Oxford, Oxford University Press, 2016) ch 2.

${ }^{38}$ See, eg, CL Elder, 'Artifacts and Mind-Independence', in Franssen et al (n 37) (though Elder's way of cashing out this thought - by treating the function of an artifact-type as fixed by reference to whatever caused past tokens of that type to be reproduced - is not particularly congenial to the present understanding of statutory purpose). I am grateful to Jan Mihal for drawing Elder's work to my attention.
} 
equivalent to its purpose. However, this is a conclusion that requires substantive argument; it should not be treated as an a priori conceptual truth. To adopt an understanding of the concept of statutory purpose from which it follows that a statute's legal effect is equivalent to its purpose would be to stack the deck against those who argue (on substantive grounds) either that statutory purpose does not contribute to legal effect or that it is only one factor that helps constitute a statute's legal effect. Thus, just as we need to distinguish between the concepts of legislative intent and statutory purpose, we also need a conceptual distinction between a statute's legal effect and its purpose.

The problem with the present proposal for understanding statutory purpose is that it threatens to collapse this distinction. I have suggested that we should understand a statute's legal effect in terms of the contribution the statute makes to the content of the law. Yet it is not clear how this differs from the role the statute plays within the broader legal system. In other words, it is unclear how - on the present proposal - the concept of statutory purpose differs from that of a statute's legal effect.

\section{Statutory Purpose as Application-Intentions}

\section{A. The Distinction between Communicative and Legal Intentions}

One might conclude from this brief survey that the prospects for developing a satisfactory account of statutory purpose are bleak. Each of the approaches I have considered seems to face considerable difficulties. However, in this Part, I shall suggest a way of developing the first approach - which links statutory purpose with the legislature's intentions - which avoids at least some of the problems identified in Section I(A). While it remains hostage to the debate about whether legislatures can have intentions, it leads to a sharper distinction between statutory purpose and legislative intent than is achieved by appealing to the distinction between general and specific intentions. As we shall see, it also possesses several other advantages.

The starting point for developing this proposal is Mark Greenberg's distinction between two types of intention that a legislature may have. ${ }^{39}$ On the one hand, there is the legislature's

\footnotetext{
39 M Greenberg, 'Legislation as Communication? Legal Interpretation and the Study of Linguistic Communication' in A Marmor and S Soames (eds), Philosophical Foundations of Language in the Law (Oxford, Oxford University Press, 2011) 241-42.
} 
communicative intention, which we might understand as its intention to convey certain information to its audience via the words used in the statute (in part, by having its audience recognise its intention to convey this information). On the other hand, there is the legislature's legal intention, which Greenberg defines as its intention 'with respect to the legal impact of the enactment'. 40

I propose that legislative intent be understood in terms of the legislature's communicative intentions, whereas statutory purpose be understood in terms of its legal intentions. ${ }^{41}$ This suggestion will require refinement as we proceed. In particular, more needs to be said about what is meant by a 'legal intention'. However, the initial attraction of this suggestion is that it shows that statutory purpose can be understood as an intention of the legislature, and yet as distinct from legislative intent. Moreover, it treats legislative intent and statutory purpose as different types of intention (the former being an intention to communicate certain information; the latter being an intention to produce a certain legal impact), rather than relying on a vague distinction between general and specific intentions.

A similar distinction can be found in some existing discussions of statutory interpretation. For example, Tom Campbell distinguishes between how legislators 'intended the words of the statute to be understood' ${ }^{42}$ and their 'further' intentions in enacting the statute (such as the policy goal they sought to achieve), and he describes the latter as the legislators' 'purpose'. ${ }^{43}$ The former set of intentions are (roughly) what I am calling communicative intentions; the latter resemble what I am calling legal intentions.

Similarly, Scott Soames distinguishes between 'what was said' in enacting a statute (which, he claims, depends on the communicative intentions that can reasonably be ascribed to

\footnotetext{
40 Ibid 241.

${ }^{41}$ I appeal to Greenberg for the limited purpose of distinguishing between communicative and legal intentions. Despite suggesting the distinction, Greenberg is sceptical about whether legislatures can have intentions, and I do not want to endorse that scepticism. More generally, I put the distinction to a different use than Greenberg. He distinguishes between communicative and legal intentions to illustrate the limits to the assistance that philosophy of language and linguistics can provide in the context of statutory interpretation (since these disciplines cannot supply an argument for focusing on communicative, rather than legal, intentions). By contrast, I propose that statutory purpose be understood in terms of the legislature's legal intentions (characterised in a particular way). Thanks to George Pavlakos for pressing me to be clearer about these matters.

42 T Campbell, The Legal Theory of Ethical Positivism (Aldershot, Dartmouth, 1996) 141.

${ }^{43}$ Ibid.
} 
the speaker) and the 'further legislative goals [that] were intended by legislators'. ${ }^{44}$ The latter look like legal intentions, to be contrasted with the legislature's communicative intentions (or, for Soames, the communicative intentions that can reasonably be ascribed to the legislature). ${ }^{45}$

My proposal for distinguishing between legislative intent and statutory purpose may also fit with some general tendencies in our thinking about these concepts. Legislative intent is often thought to bear on the statute's linguistic content, or to be limited to those intentions that the legislature conveyed via the words used in the statute. ${ }^{46}$ Understanding legislative intent in terms of communicative intentions vindicates such thoughts (on the plausible assumption that communicative intentions contribute to linguistic content). By contrast, statutory purpose is often understood in terms of the legislature's intention to make a change to the law, or to the world more generally (eg by remedying a mischief that the existing law does not address). ${ }^{47}$ This may fit with understanding statutory purpose in terms of the legislature's legal intentions (depending on precisely how we understand the notion of a legal intention).

\section{B. A Closer Look at Legal Intentions}

To properly assess my proposed way of understanding statutory purpose, we need a better grasp of what is meant by a 'legal intention'. As we have seen, Greenberg defines a legal intention as an intention 'with respect to the legal impact of the enactment'. However, the reference to 'legal impact' is ambiguous. It could be a reference to the type of impact (a legal type, as opposed to some other type) or to what is being impacted (an impact on the law). Greenberg understands legal impact in the latter way - he goes on to describe a legal intention as 'an intention, by enacting a given statute, in order to change the law in a particular way., 48 However, I shall argue that, if we are to understand statutory purpose in terms of legal intentions, we should adopt something like the former view - roughly, that a legal intention is an intention to make a change in the world by legal means.

\footnotetext{
${ }^{44}$ S Soames, 'Toward a Theory of Legal Interpretation' (2011) 6 New York University Journal of Law and Liberty $231,240$.

${ }^{45}$ Soames insists that communicative intentions should generally have priority over legal intentions (ibid 241). I shall not express a view about this issue: my aim is to suggest a certain understanding of statutory purpose, not to defend a particular role for purpose to play in statutory interpretation.

${ }^{46}$ See, eg, Ekins and Goldsworthy (n 2).

${ }^{47} \mathrm{See}$, eg, O Jones, Bennion on Statutory Interpretation, 6th edn (London, LexisNexis, 2013) 846.

${ }^{48}$ Greenberg, 'Legislation as Communication' (n 39) 242.
} 
Let us approach this issue by considering an observation of Goldsworthy's. He points out that the law-maker may have various aims when introducing a legal text - eg to establish a particular legal norm, to achieve certain beneficial consequences for the community or to acquire or retain political power. ${ }^{49}$ Any of these could potentially be understood as a 'legal intention', and hence as being the statutory purpose.

There is a broad consensus that 'ulterior' purposes, such as the acquisition or retention of political power, do not count. ${ }^{50}$ However, if we set ulterior purposes to one side, this still leaves open whether legal intentions are what we might call norm-intentions (the intention to contribute a particular norm to the content of the law) or what are often called applicationintentions (the intention that the statute produce certain outcomes or achieve certain consequences). ${ }^{51}$ Either might plausibly be said to be intentions as to what legal impact the statute will have: the norm-intention view corresponds with an understanding of legal impact as impact on the law; the application-intention view corresponds with an understanding of legal impact as impact on the world by legal means. In the rest of this Part, I shall consider which is the better way of understanding the concept of a legal intention, given the characterisation of statutory purpose in terms of legal intentions. ${ }^{52}$

\section{i. Norm-intentions}

It is tempting to understand legal intentions (and hence statutory purpose) in terms of normintentions. ${ }^{53}$ First, the legislature might be thought of as a norm-generating institution. If so, it seems natural to understand legal intentions in terms of the norms the legislature intended to generate. Second, understanding legal intentions as norm-intentions precludes treating very general intentions (eg to promote public safety) as the statutory purpose, and hence ameliorates

\footnotetext{
49 Goldsworthy, 'Functions, Purposes and Values' (n 11) 44.

50 See, eg, ibid; Campbell (n 42) 143; Soames (n 44) 250.

${ }^{51}$ Greenberg draws a similar distinction in the course of endorsing the norm-intention understanding of legal intentions: M Greenberg, 'What Makes a Method of Legal Interpretation Correct? Legal Standards vs. Fundamental Determinants' (2017) 130 Harvard Law Review Forum 105, 111 fn 19.

52 One might say that statutory purpose includes both types of intention. Indeed, this may be Goldsworthy's view. He suggests that the law-maker's intention to establish a particular norm and its desire to achieve certain beneficial consequences may both be relevant, at least when interpreting constitutions: Goldsworthy, 'Functions, Purposes and Values' (n 11) 44. However, for the reasons that follow, a consideration of the legislature's norm-intentions is unlikely to add anything to a consideration of legislative intent.

${ }^{53}$ Whether we understand legal intentions as norm-intentions or application-intentions, different provisions (or sets of related provisions) within the same Act will often be the subject of different legal intentions, and hence have different purposes. However, for convenience, I will often talk about the purpose of a statute, rather than the purpose of a statutory provision or set of provisions.
} 
some of the concerns about the use of purpose in statutory interpretation. ${ }^{54}$ It is unlikely that the legislature would intend that the norm a provision contributes to the law is that public safety is to be promoted (as opposed to intending to contribute a more specific norm, with the hope or even expectation that that norm will promote public safety). For one thing, this would leave it to the law-applier to decide how public safety is to be promoted. For another thing, a great many statutes aim to promote public safety; if this was also the norm that each of those statutes contributed to the law, then they would all have an identical legal effect.

There may appear to be a third reason to focus on norm-intentions, rather than application-intentions. We might think that, for both rule of law and separation of powers reasons, the legislature has the power only to lay down general rules, not to dictate the particular instances to which those rules apply. If so, its intention to introduce a particular norm into the law may be legally relevant, but its intention to achieve a certain consequence (where this is understood in terms of the norm applying to certain individual cases) is not.

However, there is a major obstacle to understanding legal intentions in terms of normintentions. While it is controversial what role statutory purpose plays in the interpretation of legislation, any proposed understanding of the concept of statutory purpose should leave open the possibility that it plays a distinct, non-trivial role. This requires that our understanding of statutory purpose differ from our understanding of other concepts relevant to statutory interpretation (such as legislative intent). Indeed, not only must there be a conceptual distinction, but the distinction should be drawn in such a way that we can imagine statutory purpose adding something that these other factors do not. Otherwise, we pre-judge what should be substantive debates about the appropriate role of statutory purpose by adopting a certain understanding of that concept.

If we understand legislative intent as the legislature's communicative intention and statutory purpose as its norm-intention, then there is a conceptual distinction between the two. The norm that the legislature intended to convey by enacting the statutory provision could conceivably differ from the norm it intended the provision to contribute to the content of the

\footnotetext{
${ }^{54}$ These concerns include that appeals to statutory purpose allow courts to ride roughshod over careful legislative decisions about the extent to which a particular purpose should be pursued, or about how to balance that purpose against other legislative aims: see, eg, Manning (n 9); Ekins (n 23) 250-51. The more abstract the purpose being invoked, the more pressing these concerns might be thought to be.
} 
law. However, while the two could come apart, they are unlikely to do so. The legislature has an obvious incentive to ensure that its norm-intentions are reflected in its communicative intentions. If it wants a particular norm to be added to the law, would it not want to convey that fact? The legislature can surely be expected to understand that part of the point of enacting a statutory provision is to convey (to the norm-applier and/or the norm-subjects) which norm it intends the provision to contribute to the content of the law.

Thus, the problem with understanding statutory purpose in terms of norm-intentions is that it is unlikely that the legislature's norm-intentions will differ from its communicative intentions, and hence it is unlikely that a consideration of statutory purpose will add anything to a consideration of legislative intent. While we might ultimately conclude that statutory purpose should not play a significant role in interpretation, this should turn on substantive issues (such as whether considering a statute's purpose rides roughshod over carefully crafted legislative compromises). We should try to avoid understanding the concept of statutory purpose in a way that leads to that conclusion without any need to consider those substantive issues.

We can imagine cases where the legislature's norm-intention does depart from its communicative intention. For example, the legislature may seek to introduce a secret law, and so may not want to convey the norm it intends to contribute to the content of the law. Or the legislature may mis-speak, and hence fail in its attempt to convey which norm it intends to contribute to the content of the law. Again, however, we should seek to avoid an account of statutory purpose from which it follows - on conceptual, not substantive, grounds - that purpose could only ever play a role with regard to secret laws or instances of legislative misspeaking. ${ }^{55}$

After drawing the distinction between communicative and legal intentions, Greenberg suggests that they often come apart. His main argument for this conclusion is that

\footnotetext{
${ }^{55}$ Even critics of purposivism typically allow that the role of statutory purpose extends beyond correcting instances of legislative mis-speaking: see text accompanying nn 69-71 below.
} 
lawmakers can be wrong about which specific linguistic contents will achieve their legal intentions.

Legislators frequently do not consider the statutory language with care. In addition, it is difficult to anticipate all the legal and practical consequences of specific rules. ${ }^{56}$

The claim that the legislature's communicative intentions may produce undesired consequences, due to a careless use of language or a failure to anticipate certain eventualities, is plausible. This is especially so given that a statute may remain part of the law for a considerable period of time, and hence may apply to circumstances quite different from those in which it was made.

However, Greenberg's argument does not show that the legislature's communicative intentions often come apart from its norm-intentions. Norm-intentions are intentions to contribute a particular norm to the content of the law, not to bring about certain consequences. While giving effect to the legislature's communicative intentions might often fail to bring about the consequences the legislature desired, doing so is likely to give effect to the legislature's norm-intentions (since, for the reasons already given, it is likely that the legislature will convey what norm it intends to contribute to the content of the law). ${ }^{57}$

What Greenberg's argument does establish is that the legislature's communicative intentions may often come apart from its application-intentions. The latter concern the consequences that the legislature wanted to bring about by enacting the statute. For the reasons Greenberg gives, these consequences may not be brought about by giving effect to the legislature's communicative intentions.

This is borne out by Greenberg's example of a case where the legislature's communicative and legal intentions came apart. In Saadeh v Farouki, ${ }^{58}$ Congress amended a statute with the aim of restricting diversity jurisdiction (ie the scope for an action to be brought in a federal court where the parties are citizens of different states, or one party is a citizen of a state and the other is a foreign citizen). The amendment specified that a permanent resident of

\footnotetext{
${ }^{56}$ Greenberg, 'Legislation as Communication' (n 39) 243-44.

${ }^{57}$ Even if the legislature's communicative intentions and norm-intentions did come apart, Greenberg's point would apply equally to the latter. The norm that the legislature intended to contribute to the content of the law could also bring about undesired consequences, either because it was carelessly conceived or due to a failure to anticipate certain eventualities. In circumstances the legislature did not anticipate, the norm it intended to contribute to the content of the law would be no more likely to produce the desired result than the norm it intended to communicate by enacting the statute.

58107 F3d 52 (DC Cir 1997) (discussed in Greenberg, 'Legislation as Communication' (n 39) 242-43).
} 
the United States is to be regarded as a citizen of the state in which he or she resides. This addressed the scenario where a permanent resident living in a state sues a citizen of that state (or vice versa). However, Congress appears not to have considered an alternative scenario, where a permanent resident living in a state sues a foreign citizen who is not a permanent resident of that state. In this second scenario, upholding Congress' communicative intentions would have the effect of expanding diversity jurisdiction.

The important point for our purposes is that Congress' norm-intentions did not come apart from its communicative intentions. To the contrary, Congress successfully communicated the norm it intended to contribute to the law. The problem was that it did not anticipate the second scenario, and so was mistaken in its belief that this norm would produce the desired consequences.

Things are different if we consider Congress' application-intentions. There is a conflict between the norm that Congress intended to communicate (and which it intended to add to the content of the law) and the consequences it intended to bring about by amending the statute. This appears to be Greenberg's point when he notes that Congress' communicative intentions would, in the second scenario, produce the opposite result to the one it was seeking. ${ }^{59}$

\section{ii. Application-intentions}

In the previous Section, I argued that - while understanding statutory purpose in terms of normintentions may appear attractive - it would mean that statutory purpose rarely departs from legislative intent. Thus, understanding statutory purpose in this way precludes the possibility that purpose could play a substantial role in statutory interpretation. Is there an alternative understanding of legal intentions, and hence of statutory purpose, that avoids this result?

I suggested that the main alternative to understanding legal intentions in terms of normintentions is to understand them in terms of application-intentions. As the discussion in the previous Section indicates, understanding legal intentions in terms of application-intentions does provide support for the claim that legal and communicative intentions often come apart.

\footnotetext{
${ }^{59}$ This does, however, raise a puzzle, since - as noted above - Greenberg characterises legal intentions in terms of norm-intentions, not application-intentions.
} 
It therefore renders it conceivable that statutory purpose could play a significant role in the interpretation of legislation.

However, if we are to understand statutory purpose in terms of application-intentions, we need a firmer grasp of what is meant by an application-intention. I have characterised an application-intention as an intention that the statute produce a certain outcome or achieve a certain consequence. Somewhat more formally, we can understand this in terms of an intention, on the part of the legislature, to bring about a certain state of affairs by enacting the statute. ${ }^{60}$

This characterisation of application-intentions may need further fine-tuning. For example, it may be that an application-intention is to be specified not only in terms of the state of affairs that the legislature intended to bring about by enacting the statute, but also in terms of the means by which the legislature intended to bring about that state of affairs. ${ }^{61}$ However, sticking with the more straightforward characterisation of application-intentions for now, we can see that application-intentions differ from both norm-intentions and communicative intentions (ie legislative intent) in two respects. First, the subject-matter of the intentions is different. Legislative intent and norm-intentions concern the statute's effect on the law, whereas application-intentions focus on effects in the world (ie the state of affairs the legislature intends to bring about). Second, legislative intent must, and norm-intentions typically will, be communicated by enacting the statute, whereas application-intentions need not be. The legislature may intend to bring about a certain state of affairs without intending to communicate what state of affairs it intends to bring about. It may choose simply to

\footnotetext{
${ }^{60}$ As I use the phrase, a state of affairs takes the form: X's being $Y$ (eg the state of affairs of Socrates' being wise): see M Textor, 'States of Affairs' in EN Zalta (ed), The Stanford Encyclopedia of Philosophy, Winter 2016 edn (URL: plato.stanford.edu/archives/win2016/entries/states-of-affairs/). This involves attributing a property (eg being wise) to an object (eg Socrates). In the case of statutory purposes, the property and the object may both be very complex, which can lead to a certain clunkiness when expressing the state of affairs in the form: X's being Y. I shall therefore typically express intended states of affairs more informally. However, my claim is that, in each case, the statutory purpose can be expressed in terms of an intention to bring about a state of affairs of X's being Y. (I am grateful to Larry Solum for a very helpful discussion of these issues.)

Soames suggests that we should understand statutory purpose in terms of the reasons that are publicly offered to justify enacting the statute: Soames (n 44) 250. (Goldsworthy also endorses this view: Goldsworthy, 'Functions, Purposes and Values' (n 11) 44.) While those reasons could be understood as referring to the need to introduce a particular norm into the law, they are more naturally understood as referring to the goals or policy objectives the statute is said to promote. Understood in this way, Soames' view bears some similarity to the view presented in the text. However, focusing on the state of affairs the legislature intended to bring about, rather than on its policy objectives, may facilitate precision in the specification of the statutory purpose. Legislators may also be more likely to agree about what state of affairs should be brought about than on the reasons why it should be brought about. If so, my approach may make it easier to ascribe intentions to the legislature as a whole. See further Section II(B)(iv).

${ }^{61}$ See text to $\mathrm{n} 23$ for some possible motivations for endorsing this position.
} 
communicate the norm it expects will bring about the desired state of affairs. ${ }^{62}$ Alternatively, the legislature may indicate what state of affairs it intends to bring about, not in the statute itself, but in the extrinsic materials.

In many cases, there will be more than one state of affairs that the legislature intends to bring about by enacting the statute. That is, the legislature may have multiple applicationintentions, with each application-intention being an intention to bring about a discrete state of affairs. For example, in enacting a particular tax statute, the legislature may have at least the following four application-intentions:

1. to bring about a state of affairs in which the common good is promoted,

2. to bring about a state of affairs in which a fair rate of corporate tax is paid,

3. to bring about a state of affairs in which a particular tax rebate (Y) is available to a certain type of corporation in particular circumstances $(Z)$, and

4. to bring about a state of affairs in which company $\mathrm{X}$ claims tax rebate $\mathrm{Y}$ in circumstances $Z$.

It is tempting to say that one of these four application-intentions must count as the real statutory purpose. However, this is defensible only if there is a principled basis on which to make this selection. One might doubt whether such a basis is available.

One noticeable feature of these four application-intentions is that they differ in their degree of generality. Bringing about the state of affairs in \#3 is intended to contribute to bringing about the more general state of affairs in \#2, which in turn is intended to contribute to bringing about the even more general state of affairs in \#1. Similarly, the state of affairs in \#4 is (intended to be) a particular instantiation of the obtaining of the general state of affairs in \#3.

Thus, any attempt to specify one of \#1-4 as the statutory purpose appears to face a similar difficulty to the one that led us, in Section I(A), to reject the suggestion that we should distinguish between legislative intent and statutory purpose by reference to how general the intentions are. There is no principled basis on which to specify the level of generality at which

\footnotetext{
${ }^{62}$ Ekins makes an analogous point when he argues that the legislature may communicate an intention to enact a plan without intending to convey its reasons for adopting that plan: Ekins (n 23) 250.
} 
the statutory purpose should be stated. As a result, there seems to be no principled way of selecting one of the four application-intentions and treating it as the statutory purpose.

Even if there was a principled basis on which to specify the requisite level of generality, there are occasions on which the legislature has multiple application-intentions that do not differ in terms of their degree of generality. ${ }^{63}$ For example, the legislature may have two distinct goals when enacting a statute, reflected in two discrete states of affairs that it seeks to bring about, and neither of those states of affairs may be subsumed within the other. We cannot select one of these application-intentions as the 'real' statutory purpose based on their differing degrees of generality, because they do not differ in this way.

Or consider a case where the legislature intends to bring about a state of affairs, X, by bringing about another state of affairs, Y. For example, the legislature may be concerned about children dropping out of school to traffick drugs, and might conclude that the best way to address this problem is to decriminalise the drugs in question and arrange for their distribution by the State. It therefore enacts legislation to that effect. The statute may make no reference to the issue of school dropout rates. Nevertheless, it is plausible that the legislature has both a direct application-intention (to bring about a state of affairs in which drugs are distributed by the State) and an indirect application-intention (to thereby bring about a state of affairs in which more children stay at school, rather than dealing drugs). ${ }^{64}$

We might well think that both the direct and indirect application-intentions contribute to the statutory purpose. In any case, we cannot choose between them by reference to their degree of generality, since they do not differ in this way. This can be seen from the fact that the legislature could have approached the problem from the opposite direction - it might have sought to strengthen school attendance requirements, in the hope that this would disrupt the drug trade (by ensuring that children attend school, rather than trafficking drugs during school hours). By contrast, in the example of the tax rebate, the chain of means-ends reasoning cannot be reversed in this way. It makes sense to say that the legislature intended to provide a tax

\footnotetext{
${ }^{63}$ This may raise a further problem for the suggestion, discussed in Section I(A), that we can distinguish between statutory purpose and legislative intent by reference to the degree of generality of the legislature's various intentions.

${ }^{64}$ I am grateful to Farrah Ahmed for pointing out the existence of indirect intentions, and for the example used in the text.
} 
rebate as a means of promoting the common good; it does not make sense to say that the legislature intended to promote the common good as a means of providing a tax rebate.

(The existence of indirect application-intentions suggests that, in some cases, specifying the statutory purpose is not simply a matter of specifying the legislature's application-intentions. It also involves specifying the relationship between those applicationintentions. In our example, the legislature not only intends (1) to bring about a state of affairs in which drugs are distributed by the State and (2) to bring about a state of affairs in which more children stay at school, rather than dealing drugs, but also intends (3) to bring about the latter state of affairs by bringing about the former state of affairs.)

For these reasons, we should abandon the attempt to find, in every case, a single application-intention that constitutes the statutory purpose. In many cases, the legislature will have multiple application-intentions when enacting a statute, and we will not be able to identify one of these intentions as the 'real' statutory purpose. This is not, in itself, a problem. That the legislature often - perhaps always - has more than one purpose in enacting a statutory provision is relatively uncontroversial. ${ }^{65}$ On the present proposal, this is understood in terms of the legislature having multiple application-intentions, each of which corresponds to one of the states of affairs the legislature sought to bring about by enacting the provision. More than one of these application-intentions may be legally relevant (because each contributes to, or sheds light on, the provision's legal effect), and our understanding of statutory purpose should be broad enough to encompass this multiplicity of legally relevant application-intentions.

However, not every application-intention the legislature has when enacting a statute should be regarded as part of the statutory purpose. In the next Section, I shall discuss some of the constraints on which application-intentions count; for now, I shall mention two reasons why we should want such constraints. First, treating all of the legislature's applicationintentions as relevant would risk producing an account of statutory purpose so capacious as to be robbed of utility. If a statute's purpose consisted of an indefinitely long list of applicationintentions, then appeals to purpose would be unlikely to assist in ascertaining its legal effect.

\footnotetext{
${ }^{65}$ See the oft-quoted passage from Rodriguez v United States, 480 US 522 (1987) at 525-26: 'no legislation pursues its purposes at all costs. Deciding what competing values will or will not be sacrificed to the achievement of a particular objective is the very essence of legislative choice - and it frustrates rather than effectuates legislative intent simplistically to assume that whatever furthers the statute's primary objective must be the law.'
} 
Second, once we allow that more than one of the legislature's application-intentions may be legally relevant, we must acknowledge the possibility that those application-intentions will come into conflict. Returning to the earlier example of the tax statute, it may turn out that providing the tax rebate to the relevant type of corporation does not help bring about a state of affairs in which a fair rate of corporate tax is paid, producing a conflict between applicationintentions \#2 and \#3. The possibility of such conflicts is inherent in the approach I am proposing. However, if there are constraints on which application-intentions are part of the statutory purpose, this will at least ameliorate the problem (since we need only worry about conflicts between those application-intentions that are legally relevant).

For these reasons, we should look for some constraints on which application-intentions count as part of the statutory purpose. Those constraints should be sufficiently stringent that the concept of statutory purpose is not too capacious. However, we should not expect those constraints to be so stringent that - for any given statutory provision - there is only a single application-intention that satisfies them. We can understand a statutory provision's purpose as consisting of the sub-set of the legislature's application-intentions that satisfy those constraints.

In the next Section, I offer some suggestions as to what these constraints are. The list of constraints I discuss may not be exhaustive. Moreover, many of them depend on normative considerations regarding what role purpose should play when interpreting legislation. However, this does not mean that my account breaches the methodological stricture I insisted on in earlier Sections - namely, that an account of what statutory purpose is should not prejudge substantive debates about the role purpose should play. The constraints I identify should be acceptable to any plausible account of the role that purpose should play in interpreting legislation. Therefore, they can be endorsed without taking sides in substantive debates about the proper role of statutory purpose.

\section{iii. Which Application-Intentions Count?}

Earlier, I mentioned the possibility that ulterior purposes (such as an intention that the ruling party be re-elected) could count as legal intentions, and hence as part of the statutory purpose. It might be thought that understanding statutory purpose in terms of application-intentions commits one to treating ulterior purposes as relevant in this way. This is because an ulterior 
purpose can be understood as an intention to bring about a certain state of affairs (eg the ruling party's re-election) by enacting the statute, and hence as an application-intention.

However, any plausible account of the role that purpose should play in statutory interpretation will treat ulterior purposes as irrelevant. Thus, on the present proposal, they do not fall within the sub-set of application-intentions that constitute the statutory purpose.

That ulterior purposes should not be considered when interpreting statutes is relatively uncontentious. ${ }^{66}$ Why this is so is more controversial. Soames suggests that ulterior purposes vary between legislators, and so cannot be ascribed to the legislature as a whole. ${ }^{67}$ This may often be true, and - where it is true - it precludes ulterior purposes from counting as applicationintentions of the legislature. However, it may be that some ulterior purposes can be ascribed to the legislature. For example, members of the majority party might support a statute with the intention that doing so will increase the chances of their party winning the next election. Depending on one's theory of legislative intent, this intention may be ascribable to the legislature as a whole, since it is shared by a majority of legislators. ${ }^{68}$

An alternative basis for excluding ulterior purposes is that they cannot play the roles that it has been suggested that statutory purpose might play. For example, there is broad agreement that appeals to statutory purpose are permissible to help identify a statute's linguistic content. ${ }^{69}$ Yet ulterior purposes do not provide reliable evidence of a statute's linguistic content. Those purposes are meant to be hidden, and so considering them is unlikely to shed light on what information the legislature intended to communicate to its audience by enacting the statute (information that it intended its audience to acquire, in part, by recognising its intention to communicate that information).

\footnotetext{
${ }^{66}$ See $\mathrm{n} 50$ above and accompanying text.

${ }^{67}$ Soames (n 44) 250. He adds that, in any case, such purposes are irrelevant, but he offers no further argument for this claim.

${ }^{68}$ Soames may have in mind a different account of legislative intent, which does not support ascribing this intention to the legislature as a whole. If so, his argument for excluding ulterior purposes depends on that account of legislative intent being vindicated.

${ }^{69}$ This is accepted even by textualists such as Scalia: see Scalia and Garner (n 10) 20, 56. The relevance of a statute's purpose to identifying its linguistic content is often explained on the basis that the words of the statute must be understood in context, and the statute's purpose forms part of the context: see, eg, ibid 20; Thiess $v$ Collector of Customs (2014) 250 CLR 664 at 672.
} 
It is also relatively uncontroversial to suggest that appeals to statutory purpose are permissible to help fill gaps in the law where a statute's linguistic content is ambiguous or vague. ${ }^{70}$ Yet it would not be appropriate to draw on ulterior purposes in this way. For example, a court cannot appeal to the government's intention to get re-elected to help resolve indeterminacies in a statute, without the court becoming an agent in the government's reelection campaign.

Finally, and more controversially, it has been suggested that statutory purpose can, in certain circumstances, provide a legitimate basis for departing from a statute's linguistic content. ${ }^{71}$ Again, it would be inappropriate to appeal to ulterior purposes in this context. Whatever reasons there may be for departing from a statute's linguistic content, the fact that doing so would assist the government to get re-elected cannot plausibly be said to be one of them.

Let us turn to a second constraint on which application-intentions count as part of the statutory purpose. An application-intention that is so narrow that it singles out a particular individual for favourable or unfavourable treatment is also precluded from being part of the statutory purpose. In the example of the tax statute in the previous Section, this rules out application-intention \#4 - namely, an intention to bring about a state of affairs in which company X obtains rebate $\mathrm{Y}$.

Again, multiple arguments could be offered in support of this constraint. One might appeal to an understanding of the rule of law, according to which the value of legality requires governance via general rules, rather than particular orders (or, at least, requires that particular

\footnotetext{
${ }^{70}$ Scalia and Garner (n 10) 56. Goldsworthy offers an interesting (but qualified) challenge to this consensus: Goldsworthy, 'Functions, Purposes and Values' (n 11) 52-54.

${ }^{71}$ In fact, there is broad agreement on this point. The disagreement is about when purpose should play this role. Scalia and Garner suggest that it should do so only 'in the rare case of an obvious scrivener's error' (Scalia and Garner (n 10) 57). Goldsworthy is more permissive, while still maintaining that cases where it is permissible to depart from the statute's linguistic content represent the exception, rather than the rule: Goldsworthy, Parliamentary Sovereignty (n 2) 231, 243-47. (See also Ekins (n 23) 249-50; Soames (n 44) 252-53.) For a more liberal approach, see LL Fuller, 'Positivism and Fidelity to Law - A Reply to Professor Hart' (1958) 71 Harvard Law Review 630, 661-69 (though Fuller's position is complicated: he clearly believes that the role of statutory purpose often justifies departing from what Hart would regard as the core meaning of a term, but he appears to believe - I think mistakenly - that there is a tenable account of linguistic content according to which the role he ascribes to purpose can be understood as contributing to, rather than departing from, a statute's linguistic content).
} 
orders be made by reference to general rules). ${ }^{72}$ Or one might appeal to a conception of the separation of powers, according to which the legislature has the power only to lay down general rules, not to dictate the particular instances to which those rules apply. Either of these views might be taken to support the conclusion that the legislature's intentions as to how its statutes will impact particular individuals are legally irrelevant.

A third constraint follows from the fact that we need a characterisation of statutory purpose according to which purpose could assist in resolving disputes about how to interpret statutory provisions. This, after all, is the point of appealing to statutory purpose, and so we want an understanding of the concept that is compatible with purpose playing this role. ${ }^{73}$ This rules out certain very broad application-intentions. Appealing again to the example of the tax statute, application-intention \#1 falls foul of this requirement. Knowing that the legislature intended to produce a state of affairs in which the common good is promoted is unlikely to assist in resolving interpretive disputes, given the abstractness of the concept of the common good and the many ways in which the common good can be promoted. ${ }^{74}$ (Recall that ulterior purposes have already been excluded from consideration. Thus, it cannot be argued that application-intention $\# 1$ is useful because it excludes such purposes.)

By contrast, application-intention \#2 may not breach this constraint. Knowing that the aim of the statute is to promote a fair rate of corporate tax might assist in resolving some

\footnotetext{
${ }^{72}$ See, eg, LL Fuller, The Morality of Law, revised edn (New Haven, Yale University Press, 1964) 46-49; J Raz, 'The Rule of Law and Its Virtue', in The Authority of Law, 2nd edn (Oxford, Oxford University Press, 2009) 21516.

${ }^{73}$ The requirement is not that the application-intention assist in resolving every interpretive dispute. That would be asking too much. Rather, it is that the application-intention assist in resolving some interpretive disputes. Those disputes must be ones that have actually arisen or could plausibly arise. That an application-intention assists in resolving some far-fetched interpretive dispute that is unlikely ever to arise is not enough to show that it can play the role(s) we might expect statutory purpose to play.

${ }^{74}$ This also suggests a response to an objection to my understanding of statutory purpose offered by Patrick Emerton. My approach involves distinguishing between communicative intentions (which constitute legislative intent) and application-intentions (a sub-set of which constitutes statutory purpose). Yet, the objection goes, that distinction is blurred if we characterise application-intentions as intentions to bring about a certain state of affairs. For example, one component of any communicative intention is an intention to bring about a state of affairs in which the intended audience has uptake of one's communicative intentions. However, even if this intention counts as an application-intention, it breaches the constraint discussed in the text, and so is not part of the statutory purpose. The intention to bring about a state of affairs in which the intended audience has uptake of one's communicative intentions is not the sort of intention that can assist in resolving real-life interpretive disputes.

More specific components of a communicative intention (eg the intention to communicate a specific content, $\mathrm{X}$, by enacting the statute) will not fall foul of this constraint, and could also be characterised as application-intentions (eg the intention to bring about a state of affairs in which $\mathrm{X}$ is communicated). However, treating these intentions as part of the statutory purpose would be redundant, since they have already been taken into account when considering legislative intent.
} 
interpretive disputes, because it suggests a standard of fairness, rather than (say) economic efficiency.

This third constraint not only excludes application-intentions that are too broad, such as the intention to promote the common good, but also any application-intention whose content mirrors that of the legislature's communicative intention. Treating that application-intention as part of the statutory purpose would be redundant, since it will already have been taken into account when considering legislative intent. ${ }^{75}$

This may rule out application-intention \#3, in the example of the tax statute discussed above. If, as seems likely, the legislature's communicative intention is to convey that companies of type $\mathrm{X}$ are eligible to claim tax rebate $\mathrm{Y}$ in circumstances $\mathrm{Z}$, considering an application-intention to bring about a state of affairs in which companies of type X claim tax rebate $\mathrm{Y}$ in circumstances $\mathrm{Z}$ may not add anything to a consideration of the legislature's communicative intention. ${ }^{76}$

Earlier, I suggested four application-intentions the legislature might have with regard to the tax statute. We have now seen that $\# 1$ and \#4, and quite possibly \#3, breach the constraints on which application-intentions form part of the statutory purpose. Does it follow that the (only) purpose of the tax statute is application-intention \#2 (ie to bring about a state of affairs in which a fair rate of corporate tax is paid)? Not necessarily. Application-intentions \#14 can all be identified without knowing much about the context in which the tax statute was introduced or the goal(s) the legislature thought would be promoted by providing the rebate. Once we learn more about the context, we may discover that the legislature had further application-intentions that satisfy the constraints discussed above. For example, we might find that the legislature intended to bring about a state of affairs in which local manufacturers of certain goods are better placed to compete with overseas manufacturers. ${ }^{77}$ This further

\footnotetext{
${ }^{75}$ This constraint guarantees that statutory purpose will differ from legislative intent. Not only are they different types of intention (as discussed above), but any application-intention whose content mirrors that of the legislature's communicative intention is excluded from forming part of the statutory purpose.

${ }^{76}$ I put the point tentatively, because there is a subtle difference in the content of the two intentions. The communicative intention is to convey that a permission is granted (companies of type $\mathrm{X}$ are permitted to claim the rebate), whereas the application-intention is that companies of type $\mathrm{X}$ in fact claim the rebate. Perhaps the additional information conveyed by application-intention \#3 means that it is not redundant.

${ }^{77}$ It may be that the state of affairs can be stated more specifically still (eg as one in which local manufacturers are better able to compete with overseas manufacturers by offsetting certain costs that local manufacturers incur but overseas manufacturers do not).
} 
application-intention is neither so broad nor so narrow as to fall foul of the constraints discussed above, and differs sufficiently from the legislature's communicative intention that consideration of the application-intention could assist in resolving some of the interpretive disputes that are likely to arise with regard to the statute. It may therefore represent another aspect of the statutory purpose, alongside application-intention \#2.

I have identified three relatively uncontroversial constraints on which applicationintentions count as part of the statutory purpose. There may be more. Nevertheless, as the discussion in the previous paragraph suggests, sometimes more than one application-intention will satisfy these constraints. Again, this should not come as a surprise - it is a commonplace that a statute may have more than one purpose; that legislatures sometimes intend to achieve multiple things by enacting a statute (or a provision). However, it does mean that - once we turn to consider what role statutory purpose should play in the interpretation of legislation we will need to say something about how this multiplicity of purposes is to be managed, especially in circumstances where the various application-intentions conflict.

While the existence of multiple application-intentions does raise problems, it also represents an opportunity. The multiplicity of legally relevant application-intentions potentially gives the concept of statutory purpose the flexibility necessary for it to assist in resolving a broad range of interpretive disputes.

\section{iv. Disagreement about Application-Intentions}

I shall finish by considering an important objection to my proposal that we should understand statutory purpose as a sub-set of the legislature's application-intentions. The objection is that there will often be widespread disagreement among legislators about what state of affairs the statute is meant to bring about, and hence we will not be able to attribute any applicationintention to the legislature as a whole (or, at least, no application-intention that is not so abstract as to breach the third of the constraints discussed in the previous Section). ${ }^{78}$

\footnotetext{
${ }^{78}$ In a sense, this worry is the opposite of the one considered in Section II(B)(ii) - not that the legislature has too many application-intentions, but rather that it has too few.
} 
This objection should be distinguished from a more general scepticism about whether legislatures can have intentions. As I argued in Section I(A), this general scepticism raises issues that extend well beyond our concern with understanding statutory purpose. Rather, the present objector argues that - while it may be possible for a legislature to have intentions - it is unlikely to have any application-intentions. Legislators may agree on the statutory text perhaps they even share certain communicative intentions about that text and/or agree on what norms they intend the statute to contribute to the content of the law - but there is unlikely to be agreement about what change in the world they want the statute to bring about. Very often, the objector suggests, different legislators support a statute for different reasons, and this divergence in their reasons correlates to a divergence in the state of affairs they intend the statute to produce. ${ }^{79}$ If this is right, understanding statutory purpose in terms of the legislature's application-intentions would be problematic, because it would follow that, very often, there is no statutory purpose.

One way of responding to this objection is to endorse a 'non-aggregative' account of legislative intent, according to which the legislature's intentions are not fixed by aggregating the intentions of some or all of the legislators. ${ }^{80}$ On such an account, we may be able to ascribe an application-intention to the legislature even if there is widespread disagreement among legislators about what state of affairs the statute is meant to bring about. ${ }^{81}$ Indeed, it may be that the legislature can have an application-intention that no individual legislator shares.

However, I do not want to rely on this response, because I wish to remain neutral about how intentions are to be ascribed to the legislature. Rather, I begin by pointing to two features of my account of statutory purpose that provide grounds for optimism that the existence of disagreement among legislators does not undermine that account (on any plausible theory of how intentions are to be ascribed to the legislature).

First, I need not maintain that every statute has a purpose. It may be that there are cases in which the objector is right - the disagreement among legislators is such that there is no state of affairs that the legislature as a whole intends to bring about. Provided this is not true in too

\footnotetext{
79 This is to be contrasted with cases where legislators intend the statute to bring about the same state of affairs, but desire that state of affairs for different reasons: see n 60 above.

${ }^{80}$ For one such account, see Ekins (n 23).

${ }^{81}$ This will, however, depend on what conditions the account does require to be met for an intention to be ascribed to the legislature.
} 
many cases, I can allow that my account of statutory purpose entails that some statutes lack a purpose, while maintaining that it is compatible with purpose playing an important role in the interpretation of many other statutes.

Second, recall that there can be many different states of affairs that a statute is intended to bring about. All we need is sufficient agreement on one of these application-intentions in order to ascribe a purpose to the statute (provided that application-intention satisfies the constraints discussed in the previous Section). Conversely, the objector needs to show that, for each of those intentions, there is too much disagreement among legislators for the legislature as a whole to hold the intention.

For example, where there is widespread disagreement among legislators about the specific state of affairs the statute is meant to bring about, it may be open to us to ascend the ladder of generality described in Section II(B)(ii) to find a purpose on which there is sufficient agreement. Admittedly, there may be some cases in which this purpose is too abstract to be useful. Indeed, in extreme cases, it may be that all the legislators agree on is that the statute should bring about a state of affairs in which the common good is promoted. However, on other occasions, there may be a more general characterisation of the statute's purpose that both attracts sufficient support from legislators and can assist in resolving some interpretive disputes.

Finally, it is worth challenging the suggestion that disagreement about applicationintentions is typically rampant among legislators. While attention often focuses on controversial statutes, in most jurisdictions there are many statutes that are relatively uncontentious, at least among legislators. ${ }^{82}$ If every statute was the subject of disagreement, horse-trading and ultimately compromise, it would be hard to see how modern legislatures could produce the enormous volume of legislation that most of them in fact produce. Where a statute is relatively uncontentious, we might expect legislators to share quite specific application-intentions, which can then be attributed to the legislature as a whole. ${ }^{83}$

\footnotetext{
82 Perhaps the United States is an exception; I leave that as an open question.

${ }^{83}$ Alternatively, many legislators may be indifferent to the enactment of the statute, and hence not stand in the way of those legislators who seek to bring about its enactment. I do not believe that indifference of this sort precludes an intention being ascribed to the legislature as a whole, but I shall not argue for that claim here.
} 
This suggests that we should be cautious in generalising about disagreement regarding application-intentions. In some cases, the statute may be uncontroversial, such that legislators share application-intentions with regard to it. In these cases, ascribing a purpose to the statute may be unproblematic. In other cases, legislators may diverge with regard to some applicationintentions while sharing others. For example, they may differ in terms of the specific state of affairs they intend the statute to bring about, but share an intention to bring about a more general state of affairs. Or they may agree that the statute has a direct purpose, while disagreeing about whether it also has a further, indirect purpose. In these cases, there is still a statutory purpose, but it may be limited to the application-intention(s) on which legislators agree. Finally, there may be some cases in which disagreement is so rampant that we cannot ascribe any (useful) purpose to the statute at all.

\section{Conclusion}

I have argued for a particular understanding of statutory purpose, according to which a statute's purpose consists of a sub-set of the legislature's application-intentions. An applicationintention, in turn, is to be understood as an intention to bring about a certain state of affairs by enacting the statute. Understanding statutory purpose in this way avoids many of the problems that confront other understandings of the concept. I have also identified some of the constraints that determine which of the legislature's application-intentions constitute the statutory purpose.

My focus has been on what statutory purpose is. I have not sought to ascertain what role it does or should play in statutory interpretation. Unlike some other understandings of statutory purpose, the account I have offered is compatible with purpose playing a range of different roles. Whether it does or should play any or all of those roles is a matter for further enquiry. However, my hope is that obtaining a better understanding of the concept of statutory purpose leaves us better-placed to undertake that enquiry. 


\section{University Library}

\section{- M M I N E R VA A gateway to Melbourne's research publications}

Minerva Access is the Institutional Repository of The University of Melbourne

Author/s:

Smith, D

Title:

What is Statutory Purpose?

Date:

2019

Citation:

Smith, D. (2019). What is Statutory Purpose?. Burton Crawford, L (Ed.). Emerton, $P$ (Ed.). Smith, D (Ed.). Law under a Democratic Constitution: Essays in Honour of Jeffrey Goldsworthy, (1), pp.13-37. Hart Publishing.

Persistent Link:

http://hdl.handle.net/11343/241643 